Güncel Turizm Araştırmaları Dergisi

Cilt: 4, Sayı: 1, BAHAR: 7-21, 2020

e-ISSN: 2602-3008

DOI: 10.32572/guntad.703410

\section{YENI KORONAVIRÜS (COVID-19) SALGINI VE TURIZM FAALIYETLERINE ETKISI}

\section{THE NOVEL CORONAVIRUS (COVID-19) OUTBREAK AND

\author{
IMPACT ON TOURISM ACTIVITIES
}

\author{
Dr. Öğr. Üyesi Yusuf ACAR \\ Aksaray Üniversitesi \\ yacar1986@gmail.com \\ ORCID: 0000-0003-3386-8810
}

öz

Bu çalışmanın amacı, Çin'in Vuhan şehrinde ortaya çıkan ve 'yeni koronavirüs (COVID-19)' olarak teşhis edilen (T.C.

Sağlık Bakanlığı Covid-19 Rehberi, 2020: 5; WHO, Coronavirus Disease (COVID-19) Outbrake, 2020) salgının turizm faaliyetleri üzerindeki güncel ve gelecek dönemlerdeki muhtemel etkilerinin tespit edilmesidir. Bu amaç doğrultusunda; etkileri itibariyle uluslararası halk sağlığı açısından ciddi bir tehdit arz eden salgınla ilgili olarak Dünya Sağlık Örgütü'ne (WHO) ait resmî web sitesinde sürekli güncellenen ve anlık olarak paylaşılan veriler ve talimatlar doküman analizi yöntemi ile incelenmiştir. 31 Aralık 2019 ile 10 Mart 2020 tarihleri arasında hükümetlerin tedbir niteliğinde uyguladıkları

ülkelere giriş çıkış yasakları, salgının tespit edildiği bölgelerde uygulanan karantinalar, iptali söz konusu olan uluslararası çapta spor ve sanat etkinlikleri, kongreler ve

seyahat kısıtlamaları gibi turizm sektörünü doğrudan etkileyen özel önlemler ile ilgili veriler çalışma kapsamında değerlendirilmiştir. Ayrıca çalışmada Dünya Turizm Örgütü'nün (WTO) konuya ilişkin rapor ve uyarılarına da yer verilmiştir. Çalışma bulguları sonucunda elde edilen izlenimler yeni koronavirüsün ülke ekonomilerinde etkileri uzun süre hissedilebilecek türden zararlar oluşturacağı ve turizm sektörünün de bu zararlardan doğrudan olumsuz bir şekilde etkileneceği yönündedir.

Anahtar Kelimeler: Yeni Koronavirüs, Salgın, Turizm.

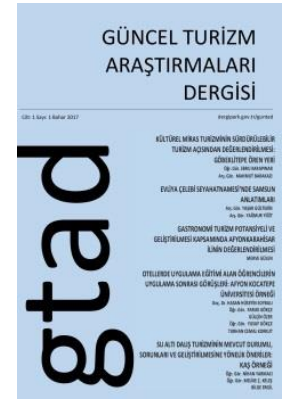

\author{
MAKALE BiLGISi \\ Literatür Araştırması \\ Makale Geliş \\ 13.03.2020 \\ Düzeltme \\ 20.03.2020 \\ Kabul \\ 23.03.2020
}

\section{ABSTRACT}

In this study, it is aimed to determine; current and future potential effects of the outbreak which is defined as the Novel Coronavirus (COVID-19) emerged Wuhan in China (Republic of Turkey Ministry of Health-19 Covid-19 Guide 2020:5; WHO, Coronavirus Disease (COVID-19) Outbrake, 2020) on tourism activities. In accordance with this purpose; research data were collected through document analysis, which are constantly updated on the official website of the World Health Organization (WHO), regarding the outbrake, which poses a serious threat to the public health in terms of its effects. Between 31 December 2019 and 10 March 2020, data related to the measures affecting the tourism sector such as the ban on entry and exit to countries applied by national governments, quarantines, international sports and art activities, travel restrictions, etc. were evaluated within the scope of the study. In addition, the reports and warnings of the World Tourism Organization (WTO) on the subject are also included in the study. The impressions obtained as a result of the study findings indicate that the new coronavirus will create damages that can be felt for a long time in the economies of the country, and that the tourism sector will be directly affected by these losses.

Keywords: The Novel

Coronavirus, Outbreak, Tourism

Atıf için: Acar, Y. (2020). Yeni Koronavirüs (Covid-19) Salgını ve Turizm Faaliyetlerine Etkisi. Güncel Turizm Araştırmaları Dergisi. 4(1), 7-21. 
Yusuf ACAR, 4 (1) 2020

- 8

\section{Giriş}

Turizm sektörü talep boyutu itibariyle meydana gelen farklı durumlara olumlu veya olumsuz bir şekilde ani tepkiler verebilen dinamik bir yapıya sahiptir. Küresel ölçekte ilgi ile takip edilen, gerçekleştirildikleri bölgelere ciddi rakamlarda ziyaretçi akışı sağlayan ve ev sahibi ülkelerde gelir yaratıcı etkiye sahip etkinlikler ya da destinasyonların sahip olduğu ve onları eşsiz kılan çekicilikler turizm sektöründen elde edilen gelirler üzerinde pozitif bir etki oluştururken; terör saldırıları, siyasi olaylar ve salgın hastalıklar gibi beklenmeyen ve yaşanması arzu edilmeyen bir dizi durum da küresel çapta seyahat ile ilgili planların değiştirilmesi, rezervasyonların iptali ve sınırların, salgının görüldüğü ülke vatandaşlarına kapatılması gibi turizm sektörü açısından olumsuz sonuçlar doğurmaktadır. Öngörülemez durumlar arasında yer alan salgın hastalıklar da ortaya çıktığı destinasyona olan güveni azaltmaktadır (Çeti ve Ünlüören, 2019: 109-110). Fakat salgın hastalıklar, terör saldırıları veya siyasi olaylardan farklı olarak ortaya çıktığı destinasyonların dışında yayılma etkisi gösterme sebebiyle küresel ölçekte bir dizi önlemin alınmasını gerektirmektedir. Destinasyon imajı ve güvenlik konusunu ele alan çalışmalar (Chapuis, Le Falher ve Gonzalez, 2015; Ilgın ve Uruç, 2018; Albayrak ve Özkul, 2013; Davras ve Uslu, 2019) bir destinasyonun güvenlik eksikliği ile ilişkilendirilmesinin özellikle tercih edilebilirlik ile ilgili endişeleri ortaya çıkardığını kanıtlar niteliktedir (Avraham, 2016: 42).

Çin Halk Cumhuriyeti, Hubei Eyaleti Vuhan şehri deniz ürünleri pazarı çalışanlarında 31 Aralık 2019 tarihinde ortaya çıkan ve 'yeni koronavirüs (COVID-19)' olarak teşhis edilen (T.C. Sağlık Bakanlığı Covid-19 Rehberi, 2020: 5; WHO, Coronavirus Disease (COVID-19) Outbrake, 2020) salgın ve turizm faaliyetlerinin ilişkilendirildiği bu çalışma kapsamında öncelikli olarak salgınla alakalı Dünya Sağlık Örgütü tarafından yapılan güncel bilimsel çalışmalar incelenmiştir. Ardından 31 Aralık 2019 ile 10 Mart 2020 tarihleri arasında Dünya Sağlık Örgütü resmî web sayfasında yayınlanan raporlar ve uyarılar nitel araştırma yöntemlerinden doküman analizi yöntemi (Bayram ve Yaylı, 2009: 359) ile incelenerek, salgının kontrol altına alınmasını sağlamak için hükümetler tarafından alınan önlemler sıralanmıştır. Doküman analizi yöntemi; konu ile ilgili basılı ve elektronik ortamda bulunan belgeleri incelemek ve değerlendirmek suretiyle, elde edilen verileri yorumlamada kullanılan sistematik süreçlerden oluşan işlemlerdir (Bowen, 2009: 27). Çalışma, salgın kaynaklı vakalarda meydana gelen ölüm oranlarındaki artışa bağlı olarak bütün dünya ulusları tarafından kaygıyla takip edildiği için, yeni virüsün oluşturacağı olumsuz etkilerin turizm sektörü açısından değerlendirilmesi bakımından önemlidir. Elde edilen veriler özellikle uluslararası seyahatlerin, yerel düzeyde ortaya çıkan bu 
salgını kanatlandırarak dünyanın farklı yerlerine yayılmasında önemli bir role sahip olduğunu göstermektedir.

\section{LITERATÜR TARAMASI}

Dünya Sağlık Örgütü'nün resmî web sitesinde yer alan ve birçok dile çevrilen Koronavirüsler ile ilgili tanımlama ve bilgiler doğrultusunda T.C. Sağlık Bakanlığı Türkiye Hudut ve Sahiller Sağlık Genel Müdürlüğü tarafından 10 Ocak 2020 tarihinde Koronavirüsler Raporu ve T.C. Sağlık Bakanlığı, Halk Sağlığı Genel Müdürlüğü tarafından 21 Şubat 2020 tarihinde yayımlanan COVID-19 (2019-n CoV Hastalı̆̆ı) Rehberi'nde Çin kaynaklı yeni virüs ile ilgili şu bilgiler yer almaktadır (WHO, Health Topics, Coronavirus, 2020; T.C. Sağ ık Bakanlığı Covid-19 Rehberi, 2020 ve T.C. Sağlık Bakanlığı, Koronavirüsler Raporu, 2020):

"Coronavirus'ler (CoV), soğuk algınlığından Orta Doğu Solunum Sendromu (MERS-CoV) ve Ağır Akut Solunum Sendromu (Severe Acute Respiratory Syndrome, SARS-CoV) gibi daha ciddi hastalıklara kadar çeşitli hastalıklara neden olan büyük bir virüs ailesidir. Yeni koronavirüs, daha önce insanlarda tanımlanmamıştır. Bu yeni virüs, soğuk algınlığı, SARS ve MERS gibi virüsleri de içeren bir virüs ailesi olan koronavirüs olup geçici olarak "2019-nCoV." olarak adlandırılmıştır. 12 Şubat 2020 itibariyle COVID-19 olarak güncellenmiştir. Coronavirus'lar zoonotik olup, hayvanlardan bulaşarak insanlarda hastalık yapabilir. Detaylı araştırmalar sonucunda, SARS-CoV'un misk kedilerinden, MERS-CoV'un ise tek hörgüçlü develerden insanlara bulaştığı ortaya çıkmıştır."

Ortaya çıktığı andan itibaren dünyanın gündemine oturan yeni koronavirüs ile ilgili başta sağlık alanında olmak üzere çok sayıda yeni bilimsel çalışma yapılmıştır. Bu çalışmalar genelde virüsün tanımı, yayılma alanı ve korunma yolları ile ilgili bilgiler içermektedir. Dünya Sağlık Örgütü resmî web sayfasında Koronavirüs ile ilgili özellikle seyahat başta olmak üzere salgınla ilgili genel değerlendirmelerde bulunan çalışmalar şu şekildedir (WHO Global Research on Coronavirus Disease, 2020):

Mahase (2020) tarafından yapılan çalışmada WHO verilerine göre virüsün yayılmasını takip eden süreçte, maske gibi kişisel koruyucu ekipman ve solunum cihazlarına olan talebin normal seviyelere göre 100 kat ve ilgili malzeme fiyatlarının da yaklaşık 20 kat artış gösterdiği belirtilmektedir.

Columbus, Brust ve Arrogila (2020) tarafından yapılan çalışmada 11 Şubat 2020 tarihine kadar olan süreçte, yeni virüsün dünya üzerindeki yayılma alanları ve küresel düzeyde oluşturduğu tehditlerden bahsedilmektedir.

Yeni Koronavirüs (COVID-19) Salgını ve Turizm Faaliyetlerine Etkisi 
Yusuf ACAR, 4 (1) 2020

- 10
Ahmad, Khan, Khan ve Hui (2020) tarafından yapılan çalışmada Çin'de ortaya çıkan ve hızlı bir biçimde dünyaya yayılmaya başlayan virüs ile ilgili istatistiki bilgiler verilerek, Pakistan'ın Çin'e olan coğrafi yakınlığından ve ticari ilişkilerinden dolayı yüksek risk altında olduğu belirtilmektedir.

Chen, Yang, Yang, Wang ve Bärnighausen (2020) tarafından yapılan çalışmada Çin'in yeni yıl kutlamaları esnasında oluşan kitlesel nüfus hareketlerine bağlı duyulan kaygıdan ve COVID-19 için alınması gereken önlemlerden bahsedilmektedir.

Rodriguez-Morales, Gallego, Escalera-Antezana, Mendez, Zambrano, Franco-Paredes, Suárez, Rodriguez-Enciso, Balbin-Ramon, Savio-Larriera, Risquez ve Cimerman (2020) tarafından yapılan çalışmada tarihsel süreç içerisinde birçok salgınla uğraşmak zorunda kalan Brezilya'da onaylanan ilk koronavirüs vakası sonucunda 640 milyon nüfusa sahip Latin Amerika ülkelerine uyarılarda bulunulmaktadır.

Ayittey, Ayittey, Chiwero, Kamasah ve Dzuvor (2020) tarafından yapılan çalışmada koronavirüsün Çin ve Dünya ekonomisine olan etkileri araştırılmış ve virüsün yılın ilk çeyreğinde Çin ekonomisini yaklaşık 62 milyar dolar ve dünya ekonomisini de $\mathbf{2 8 0}$ milyar doları aşan zarara uğratacağının tahmin edildiği belirtilmiştir.

Quilty, Clifford, CMMID nCoV Working Group, Flasche ve Eggo (2020) tarafından yapılan çalışmada havaalanları giriş ve çıkışlarında salgının kontrol altına alınabilmesi için son derece önemli olan termal kamera taramalarının etkinlikleri değerlendirilmiş ve enfekte olmuş yolcuların\%46'sının (\%95 güven aralığı: 36 ila 58) tespit edilemeyeceği belirtilmiştir.

Chiodini (2020) tarafından yapılan çalışmada Dünya Sağlık Örgütü tarafından virüsle ile ilgili yapılan tanımlar ve muhtemel korunma yolları hakkında bilgiler sunmakla birlikte, küresel çapta yapılacak iş birliklerinin önemi vurgulanmaktadır.

Bogoch, Watts, Thomas-Bachli, Huber, Kraemer \& Khan (2020) tarafından yapılan çalışmada virüsün etki alanının genişlemesi ve oluşabilecek muhtemel sorunlar değerlendirilmektedir. Du, Wang, Chauchemez, Xu, Wang, Cowling ve Meyers (2020) tarafından yapılan çalışmada koronavirüsün ortaya çıktığı Vuhan şehrinden Çin'de bulunan 369 şehre yayılma olasılığı tahmin edilmiştir.

Wilson ve Chen (2020) tarafından yapılan çalışmada Çin'in Vuhan kentinden dünyanın farklı yerlerine yapılan seyahatlerin virüsün yayılmasına olan etkilerinden bahsedilmiştir. 
Dünya Sağlık Örgütü resmî web sayfasında yeni koronavirüs ile ilgili son dönemde yapılmış çalışmalar, özellikle uluslararası seyahat hareketlerinin virüsün küresel çapta tehdit oluşturmasında önemli bir role sahip olduğunu göstermektedir. Ayrıca ölümcül salgının etki alanını genişletmesi ile birlikte dünya genelinde özellikle solunumla ilgili sağlık malzemelerine olan talebin katlanarak artacağı ve virüsün dünya ekonomisine büyük darbe vuracağı görüşü hâkimdir.

\section{DÜNYA GENELINDE YENI KORONAVIRÜS (COVID-19) ISTATISTIKLERI ve TURIZM FAALIYETLERINE ETKILERI}

Çalışmanın bu kısmında, yeni koronavirüs ile ilgili Dünya Sağlık Örgütü ve Dünya Turizm Örgütü resmî web sayfalarında 31 Aralık 2019 ile 10 Mart 2020 tarihine kadar geçen süreçte yayınlanan raporlar, yapılan uyarılar doküman analizi yöntemi ile incelenmiş ve uluslararası açıdan tehdit oluşturan ölümcül virüse yönelik küresel çapta alınan önlemler sıralanmıştır.

Dünya Sağlık Örgütü, yeni koronavirüs ile ilgili güncel verileri (onaylanmış vaka sayıları, virüs kaynaklı ölümler, virüsün tespit edildiği ülkeler vb.) 21 Ocak 2020 tarihinden itibaren günlük olarak "Durum Raporu" başlığı altında resmî web sitesinde yayınlayarak dünya kamuoyunu kaygı verici gelişmeler Yeni Koronavirüs (COVID-19) Salgını ve Turizm Faaliyetlerine Etkisi hakkında sürekli bilgilendirmektedir (WHO, Situation Reports, 2020).

Dünya Sağlık Örgütü tarafından 9 Mart 2020'de yayınlanan 8 Mart 2020 tarihli 48 no'lu durum raporu şu şekildedir (WHO, Coronavirus disease 2019 (COVID-19) Situation Report -48):

Bulgaristan, Kosta Rika, Faroe Adaları, Fransız Guyanası, Maldivler, Malta, Martinik ve Moldova Cumhuriyeti'nde yeni koronavirüs vakaları bildirilmiştir.

Son eklenen rakamlarla birlikte virüs dünya genelinde 101 ülkeye yayılmıştır.

Dünya Sağıık Örgütü, ülkelerin virüsle etkin mücadele edebilmesi için müdahale rehberlik paketi yayımlamıştır.

Virüsle ilgili istatistiki bilgilerin sunulduğu 'Sayılarla Durum' başlığı altında dünya genelinde toplam 105.586 kişide (3656'si son 24 saat içinde), Çin'de 80.859 kişide (27'si son 24 saat içinde) ve Çin dışındaki ülkelerde 24.727 kişide (3610'u son 24 saat içinde) yeni koronavirüs vakası tespit edilmiştir.

Virüs kaynaklı ölüm oranları incelendiğinde salgından Çin'de 3100 kişi (27'si son 24 saat içinde) ve Çin dışında 484 kişinin (71'i son 24 saat içinde) hayatını kaybettiği görülmüştür. 
Dünya Sağlık Örgütü resmî web sitesinde 10 Mart 2020 tarihinde yayınlanan 9 Mart 2020 tarihine ait 49 no'lu durum raporu ise şu şekildedir (WHO, Coronavirus disease 2019 (COVID-19) Situation Report -49):

- Virüs; Bangladeş, Arnavutluk ve Paraguay olmak üzere 3 ülkede daha rapor edilmiştir. Son eklenen rakamlarla birlikte virüs dünya genelinde 104 ülkeye yayılmıştır.

- Salgının başlangıcından bu yana 57 ülkeye 584.000 'den fazla cerrahi maske, 47.000 N95 maske, 620.000 eldiven, 72.000 önlük ve 11.000 gözlük sevk edilmiştir.

- Son durum raporunun yayınlanmasının ardından Çin'de 80.904 (45'i yeni) ve Çin dışında 28.673 (3948'i yeni) olmak üzere dünya

Yusuf ACAR, 4 (1) 2020

- 12 genelinde toplam 109.577 (3993'ü yeni) vaka onaylanmıştır.

- Hastalık kaynaklı ölüm sayısı Çin'de 3123 (23'ü yeni), Çin dışında 686 (202'si yeni) olmak üzere toplamda 3809 (225'i yeni) rakamların ulaşmıştır.

- Çin'de salgın kaynaklı en fazla ölüm Hubei eyaletinde (3007) gerçekleşmiştir.

- Çin dışında salgın kaynaklı en fazla ölüm İtalya (366) ve İran'da (194) gerçekleşmiştir.

Dünya Sağlık Örgütü resmî web sitesinde 11 Mart 2020 tarihinde yayınlanan 10 Mart 2020 tarihine ait 50 no'lu durum raporu ise şu şekildedir (WHO, Coronavirus disease 2019 (COVID-19) Situation Report 50):

- Virüs; Brunei Sultanlığı, Moğolistan, Kıbrıs, Guernsey ve Panama olmak üzere 5 ülkede daha rapor edilmiştir. Son eklenen rakamlarla birlikte virüs dünya genelinde 109 ülkeye yayılmıştır.

- 9 Mart 2020 tarihi itibariyle toplam 45 taraf devlet, Dünya Sağlık Örgütüne COVID-19 salgını ile ilgili uyguladıkları ek sağlık önlemleri hakkında bilgi vermiştir.

- Son durum raporunun yayınlanmasının ardından Çin'de 80.924 (20'si yeni) ve Çin dışında 32.778 (4105'i yeni) olmak üzere dünya genelinde toplam 113.702 (4125'i yeni) vaka onaylanmıştır.

- Salgın kaynaklı ölüm sayısı Çin'de 3140 (17'si yeni), Çin dışında 872 (186'sı yeni) olmak üzere toplamda 4012 (203'ü yeni) rakamlarına ulaşmıştır.

Salgına ait 48-49 ve 50 numaralı başlıklar ile yayınlanan durum raporları virüsün küresel çapta açtığı tahribatı gözler önüne sermeye yetmektedir. Uluslararası halk sağlığını tehdit eden bu yeni salgına karşı Dünya Sağlık Örgütü'nün talimatları doğrultusunda bütün dünya kırmızı alarma geçmiş 
durumdadır. Virüs ile ilgili yakın zamanlı bilimsel çalışmalar da incelendiğinde virüsün dünya geneline yayılmasında, virüsü taşıyan kişilerin yaptıkları seyahatlerin etkili olduğu anlaşılmaktadır (Wilson ve Chen, 2020: 2). Bu durum da ulusal hükümetleri seyahat sağlığı konusunda bir dizi önlem almaya itmektedir. Virüsün yayılmasını yavaşlatmak ve durdurmak için alınan seyahat tedbirlerinin etkilediği sektörlerin başında turizm gelmektedir.

Dünya Turizm Örgütü yaşanan gelişmeleri ilgiyle ve kaygıyla takip ederek, uluslararası toplum sağlığı açısından tehdit arz eden bu salgına karşı Dünya Sağlık Örgütü'nün tedbir kararlarını referans alarak resmî web sayfasından yapmış olduğu duyurular ile özellikle seyahat eden ve seyahat planları olan kişileri sorumlu bir biçimde sürekli uyarmaktadır. Dünya Turizm Örgütü tarafından yapılan uyarılarda, durumun turizm sektörü açısından vahamet taşısa da önceliğin insan ve toplum sağlığı olduğu önemle vurgulanmaktadır (UNWTO, Tourism and Coronavirus Disease (COVID-19), 2020).

Dünya Turizm Örgütü resmî web sayfasında 31 Ocak 2020 tarihinde koronavirüs ile ilgili yayınlanan dokümanda Çin'de ortaya çıkarak kısa süre içerisinde dünya çapında tehdit oluşturan salgın ile ilgili gelişmelerin anlık takip edildiği ve Dünya Sağlık Örgütü ile yakın işbirliği içerisinde olduğu

Yeni Koronavirüs (COVID-19) Salgını ve Turizm Faaliyetlerine Etkisi belirtilmektedir. Aynı dokümanda turizmin sorumluluğu başlığı altında turizm sektörünün insanları ve refahlarını ilk sıraya koyarak, turizm sektörünün göstereceği hassasiyet ve iş birliğinin salgının durdurulmasında hayati öneme sahip olacağı vurgulanmaktadır (UNWTO Statement on the Novel Coronavirus Outbreak, 2020).

Dünya Turizm Örgütü resmî web sayfasında 6 Mart 2020 tarihinde güncellenerek yayınlanan "Turizm ve Koronavirüs Salgını" adlı başlıkta turizm sektörünün sahip olduğu sosyal yönü ile toplumlar arası etkileşimden diğer ekonomik faaliyetlerden daha fazla etkilendiği ve Çin'de ortaya çıkan salgının turizm sektörü başta olmak üzere küresel çapta birçok sektörü etkilediği ve etkileyeceği belirtilmektedir (UNWTO Tourism and Coronavirus Disease (COVID-19), 2020).

Dünya Turizm Örgütü resmî web sayfasında 5 Mart 2020 tarihinde güncellenerek yayınlanan "COVID-19 Salgınının Uluslararası Turizm Üzerindeki Etki Değerlendirmesi" adlı dokümanda yer alan anahtar mesajlar şu şekilde belirtilmiştir (UNWTO Impact Assessment of the COVID19 Outbreak on International Tourism, 2020):

Küresel çapta seyahat kısıtlamaları ve uçuş iptalleri devam ederken, ulusal ve uluslararası ölçekte seyahat hizmetlerinin arzı salgına bağlı olarak önemli ölçüde azalmıştır. 
Virüsün etki alanı ve yayılma hızı göz önüne alındığında, COVID-19'un uluslararası turizm üzerindeki etkilerini tahmin etmek için henüz çok erkendir.

COVID-19'un coğrafi etki alanı ve yayılma hızı hesaba katıldığında, salgının küresel turist hareketliliğini \%1 ila \%3 oranında azalttığı tahmin edilmektedir. İlgili durum, uluslararası turizm gelirlerinde yaklaşık 30 ila 50 milyar Amerikan doları kayıp anlamına gelmektedir.

Asya ve Pasifik Bölgesi'nin salgın nedeniyle turist hareketliliğinden en fazla etkilenen bölge olması beklenmektedir.

COVID-19 uluslararası düzeyde bütün turizm faaliyetlerini etkileyecektir. Turizm sektörü içerisinde faaliyet gösteren küçük ve orta ölçekli

Yusuf ACAR, 4 (1) 2020

- 14 işletmelerde bu zararların daha fazla hissedileceği öngörülmektedir.

Yukarıda yer alan bilgiler ve Dünya Turizm Örgütü resmî web sayfasında salgın ile ilgili yer alan dokümanlar, salgının uzun vadede dünya turizmini olumsuz etkileyeceğini gösterir niteliktedir.

Dünya Sağlık Örgütü tarafından salgının durdurulması ve kontrol altına alınmasına yönelik eylemlerde ulusal yönetimlere ciddi görevler düşmektedir. Ulusal yönetimler tarafından salgının ortaya çıktığı andan itibaren uluslararası sağlık ve güvenlik konuları dikkate alınarak katı bir biçimde uygulanan ülkelere giriş çıkış yasakları, salgının tespit edildiği bölgelerde uygulanan karantinalar, iptal edilen ya da iptali söz konusu olan uluslararası çapta spor ve sanat etkinlikleri ile seyahat kısıtlamaları salgınla mücadelede önem arz etmektedir. Dünya Sağlık Örgütü'nün uyarıları ve yayınladığı raporlar doğrultusunda yukarıda sayılan ve ulusal hükümetler tarafından uygulanan önlemler şu şekilde örneklendirilebilmektedir:

- Başta Çin olmak üzere salgının tespit edildiği ülke ve bölgelerde halk sağlığını korumaya yönelik uygulanan geniş çaplı karantinalar ve seyahat kısıtlamaları.

- Salgının yoğun olarak hissedildiği ve salgına bağlı olarak ölüm olaylarının yaşandığı Çin, İtalya, İran ve Moğolistan için Sağıık Bakanlıklarının yapmış oldukları seyahat uyarıları (T.C. Sağık Bakanlığı Seyahat Sağlığı, 2020).

- 10 Mart 2020 tarihinden itibaren COVID-19 salgını nedeniyle tüm İtalya'nın karantina altına alınması (İtalya Sağlık Bakanlığı, 2020).

- İtalya'da bütün eğitim kurumlarının en az 3 Nisan 2020 tarihine kadar eğitime ara vermesi, seyahat kısıtlamaları ve italya Ulusal Futbol Ligi Seria A'nın da içinde bulunduğu sportif organizasyonlarda 3 Nisan 2020 tarihine kadar müsabakaların askıya alınması (Italya ve Koronavirüs, 2020). 
- Dünya genelinde havayolu işletmelerinin salgının yoğun olarak görüldüğü ülkelere seferlerini iptal etmesi.

- UEFA tarafından düzenlenen ve dünya çapında ilgiyle takip edilen Şampiyonlar Ligi ve UEFA Avrupa Ligi müsabakalarının seyircisiz oynanması.

- Salgının yoğun olarak etkilediği bölgelerden gelen yolcuların kabul edilmemesi ve özellikle havaalanlarında, hudut ve gümrüklerde geniş çaplı güvenlik önlemlerinin alınması.

- Salgının etkisi altına aldığı ülkelerde eğitime ara verilmesi.

- Dünyanın en çok ziyaretçi kabul eden Louvre gibi müzelerin salgın sebebiyle ziyaretlere kapatılması.

- Salgın sebebiyle Katolik mezhebinin merkezi olan Vatikan'da binlerce insanın katılımıyla pazar günleri gerçekleşen ayinin Papa tarafından çevrimiçi olarak gerçekleştirilmesi.

- Dünya genelinde geniş çaplı katılımlara sahip ve oluşturduğu ekonomik etkiler ile ülkeler açısından önemli festival, konser, kongre ve fuarlar gibi kültürel ve sanatsal faaliyetlerin iptal edilmesi.

- Dünya turizm pazarı açısından önemli bir bölge olan Uzak Doğu ve Çin pazarına yönelik uygulanan seyahat kısıtlamaları ve rezervasyon iptalleri gibi uygulamaların; başta ulaşım ve konaklama olmak üzere

Yeni Koronavirüs (COVID-19) Salgını ve Turizm Faaliyetlerine Etkisi

Yukarıda dünya basınında sıklıkla yer alarak sıralanan ve Dünya Sağlık Örgütü'nün talimatları ile ulusal hükümetler tarafından gün geçtikçe yenileri eklenerek alınan önlemler, küresel ölçekte infiale sebebiyet vermektedir. Salgının etki alanı ve salgınla ilişkili ölüm vakalarında yaşanan artış ulusal hükümetleri daha geniş çaplı önlemler almaya itmektedir.

\section{SONUÇ VE ÖNERILER}

Çin'in Vuhan şehrinde ortaya çıktığı andan itibaren kısa süre içerisinde dünyaya yayılan ve etkileri itibari ile uluslararası sağlık otoritelerini harekete geçiren yeni koronavirüs ile ilgili Dünya Sağlık Örgütü tarafından yapılan çalışmalar ve yayınlanan raporlar tüm dünya tarafından ilgi ve kaygıyla takip edilmektedir. Çin'den yayılarak uluslararası halk sağlığını tehdit eden bu yeni salgına karşı Dünya Sağlık Örgütü'nün talimatları doğrultusunda ulusal yönetimler de halk sağlığının korunması ve salgından en az hasarla kurtulabilmek için çeşitli önlemler almaktadır. Fakat önlemlerin katılaştırılmasına rağmen salgının etki alanı ve salgına bağı olarak gelişen ölüm vakalarında sürekli artış gözlemlenmesi uluslararası düzeyde ciddi kaygılara sebebiyet vermektedir. Yeni koronavirüs olarak adlandırılan bu salgının çalışma kapsamında turizm ile ilişkilendirilmesinin 
Yusuf ACAR,

- 16 altında yatan en önemli sebep; hastalığın yayılmasında ve etki alanının genişlemesinde son derece etkili olan uluslararası seyahatler konusunun altının çizilmesidir. Uluslararası seyahatler, yerel düzeyde ortaya çıkan bu salgını kanatlandırarak dünyanın farklı yerlerine yayılmasında önemli bir role sahip olmuştur. Dünya Sağlık Örgütü'nün talimatları doğrultusunda ulusal yönetimler öncelikli olarak; sınır güvenliklerine ve hastalığın etkili olduğu bölgelerden gelebilecek tehlikelere karşı güvenlik tedbirlerini arttırma yoluna gitmişlerdir. Ulusal yönetimler tarafından salgının ortaya çıktığı andan itibaren uluslararası sağlık ve güvenlik konuları dikkate alınarak katı bir biçimde uygulanan önlemleri genel olarak şu şekilde sınıflandırmak mümkündür:

- Arttırılan sınır güvenlikleri ve ülkelere giriş çıkış yasakları

- Salgının tespit edildiği bölgelerde uygulanan karantinalar

- Salgının yayılmasına yönelik kamusal alanlarda yapılan dezenfeksiyon uygulamaları

- İptal edilen ya da iptali söz konusu olan ulusal ve uluslararası düzeyde spor ve sanat etkinlikleri

- Sokağa çıkma yasakları

- Seyahat kısıtlamaları

- Eğitime ara verilmesi uygulamaları

Çalışmanın amacı doğrultusunda Dünya Sağlık Örgütü ve Dünya Turizm Örgütü'ne ait resmî web sitesinde yayınlanan raporlar ve bilimsel çalışmalar incelendiğinde; salgının ortaya çıktığı andan itibaren dünya genelinde koruyucu maske, eldiven gibi sağlık malzemelerine olan talebin arttığı ve talep artışına bağı olarak ilgili sağlık malzemelerin fiyatlarında da ciddi artışların meydana geldiği saptanmıştır (Mahase, 2020: 1). Ayrıca virüsün Çin ve Dünya ekonomisine olan etkilerini inceleyen çalışmalarda virüsün yılın ilk çeyreğinde Çin ekonomisini yaklaşık 62 milyar dolar ve dünya ekonomisini de 280 milyar doları aşan zarara uğratacağı tahmin edilmektedir (Ayittey vd., 2020).

Dünya Turizm Örgütü'ne ait raporlar incelendiğinde; virüsün etki alanı ve yayılma hızı göz önüne alındığında COVID-19'un uluslararası turizm üzerindeki etkilerini tahmin etmek için henüz çok erken olduğu ve salgının uluslararası düzeyde bütün turizm faaliyetlerini etkileyeceği vurgusu yapılmıştır. Ayrıca; ulusal ve uluslararası ölçekte seyahat hizmetleri arzının salgına bağlı olarak önemli ölçüde azaldığı ve salgının küresel turist hareketliliğini \%1 ila \%3 oranında azalttığı, bu durumunda uluslararası turizm gelirlerinde yaklaşık 30 ila 50 milyar Amerikan doları kayıp anlamına geleceği belirtilmiştir (UNWTO Impact Assessment of the COVID-19 Outbreak on International Tourism, 2020). 
Salgının başta toplum sağlığı olmak üzere ekonomik, çevresel, sosyolojik ve kültürel etkilerini de göz ardı etmemek gerekir. Çünkü uluslararası düzeyde tehdit oluşturan ve tedavisi bulunmayan bu ve benzeri olaylarda uzman ve yetkililerin belirlediği çizgiler içerisinde hareket etmek oluşabilecek riskleri en aza indirmek açısından önem arz etmektedir. Gelecek dönemlerde virüsün toplum sağlığı üzerindeki olumsuz etkilerini en aza indirebilmek için her bireye ayrı ayrı vazifeler düşmektedir. Başta Dünya Sağlık Örgütü olmak üzere ulusal düzeyde sağlıktan sorumlu yetkili birimlerin talimat ve uyarılarına uymak, bilinçli davranmak, kişisel sağlığa ve bağışıklık sistemini güçlendirmeye yönelik beslenmeye dikkat etmek gibi önemli ayrıntılar salgınlara karşı verilen mücadelede etkili olabilmektedir. Sonuç olarak çalışma kapsamında yapılan incelemeler ve elde edilen bulgular Çin'den dünyaya yayılan ölümcül virüsün küresel ölçekte etkileri uzun süre hissedilebilecek türden zararlar oluşturacağı ve diğer birçok sektör gibi turizm sektörünün de bu zararlardan doğrudan olumsuz bir şekilde etkileneceği yönündedir. Bu çalışmada 31 Aralık 2019 ile 10 Mart 2020 tarihleri arasında WHO tarafından yayımlanan raporlar analiz edilerek salgınla mücadele kapsamında hükümetler tarafından alınan tedbirler değerlendirilmiştir. Dünyanın yakından takip ettiği yeni korona virüsü ile ilgili gelecek dönemlerde yayımlanacak raporlar ile uzun vadede salgının etkileri ve salgınla mücadelede hükümetler tarafından alınan önlemler sosyal bilimlerin farklı disiplinlerinde çalışmalar yürüten araştırmacılar tarafından değerlendirilebilir.

\section{TEŞEKKÜR}

Çalışmanın hazırlandığı andan itibaren içerdiği güncel verilerden dolayı çalışmayı değerli bularak yayın sürecine dâhil eden ve yayın süreci esnasında göstermiş oldukları hassasiyetten ötürü çalışmaya değerli görüşleri ile son halinin verilmesinde önemli katkılar sunan herkese teşekkür ederim.

\section{KAYNAKÇA}

Albayrak, A. ve Özkul, E. (2013). Y Kuşağı Turistlerin Destinasyon İmaj Algıları Üzerine Bir Araştırma. Turkish Studies-International Periodical For The Languages, Literature and History of Turkish or Turkic, 8(6), Spring 2013, 15-31.

Ahmad, T., Khan, M., Khan, F.M. ve Hui, J. (2020). Are we ready for the new fatal Coronavirus: scenario of Pakistan?. Human Vaccines \&Immunotherapeutics, DOI: 10.1080/21645515.2020.1724000

Avraham, E. (2016). Destination Marketing and İmage Repair During Tourism Crises: The Case of Egypt. Journal of Hospitality and
Yeni Koronavirüs (COVID-19) Salgını ve Turizm Faaliyetlerine Etkisi 
Tourism Management, 28, 41-48.

Ayittey, F.K., Ayittey, M. K., Chiwero, N. B., Kamasah, J. S. ve Dzuvor, C. (2020). Economic Impacts of Wuhan 2019-nCoV on China and the World. Journal of Medical Virology, 10.1002/jmv.25706. https://onlinelibrary.wiley.com/doi/epdf/10.1002/jmv.25706, (Erişim Tarihi: 06.03.2020).

Bayram, M. ve Yaylı, A. (2009). 'Otel Web Sitelerinin İçerik Analizi Yöntemiyle Değerlendirilmesi. Elektronik Sosyal Bilimler Dergisi, Kış, 8 (27), 347-379.

Bogoch, I. I., Watts, A., Thomas-Bachli, A., Huber, C., Kraemer, M. U. G., ve Khan, K. (2020). Potential for global spread of a novel coronavirus

Yusuf ACAR, 4 (1) 2020

- 18 from China. Journal of travel medicine, 2020, 1-3.

Bowen, G. A. (2009). Document Analysis as A Qualitative Research Method. Qualitative Research Journal, 9 (2), 27-40.

Chapuis, J.M., Le Falher, C. ve Gonzalez, M. (2015). Destination image, perceived risk and intention to visit. Faculty of Tourism (IREST), University Paris1 Panthéon-Sorbonne, Working Paper-1, 1st June 2015.

Chen S, Yang J, Yang W., Wang C. ve Bärnighausen T. (2020). COVID-19 control in China during mass population movements at New Year. Published Online February 20, 2020 https://doi.org/10.1016/ S0140-6736(20)30421-9. The Lancet, 395 (10226), 7-13 March 2020, 764-766.

Chiodini, J. (2020). Maps, masks and media-Traveller and practitionerre sources for 2019 novel coronavirus (2019-nCoV) acute respiratory virüs. Travel Medicine and Infectious Disease 33 (2020). 101574.

Columbus, C., Brust, K.B. ve Arroliga, A.C. (2020). 2019 Novel coronavirus: an emerging global threat. Baylor University Medical Center Proceedings, DOI: 10.1080/08998280.2020.1731272, 1-4.

Çeti, B. ve Ünlüönen, K. (2019). Salgın Hastalıklar Sebebiyle Oluşan Krizlerin Turizm Sektörü Üzerindeki Etkisinin Değerlendirilmesi. AHBVÜ Turizm Fakültesi Dergisi, 22 (2), 109-128.

Davras, Ö. ve Uslu, A. (2019). Destinasyon Seçimini Belirleyen Faktörlerin Destinasyon Memnuniyeti Üzerindeki Etkisi: Fethiye'de İngiliz Turistler Üzerinde Bir Araştırma. Manas Sosyal Araştırmalar Dergisi, 8(1): 679-696

Du, Z., Wang, L., Chauchemez, S., Xu, X., Wang, X., Cowling. BJ. ve Meyers, 
L.A. (2020). Risk for transportation of 2019 novel coronavirus disease from Wuhan to other cities in China. Emerg Infect Dis. 26 (5). May. https://doi.org/10.3201/eid2605.200146. (Erişim Tarihi: 09.03.2020).

Ilgın, H.Ö. ve Uruç, H. (2018). Destinasyon İmajı Araştırmaları Perspektifinden Marmara Ereğlisi Üzerine Bir Değerlendirme. Sosyal Bilimler Metinleri Yıl:2018, Sayı: 02.

İtalya Sağlık Bakanlığı, İtalya'da Sınırlama Önlemleri (2020). http://www.salute.gov.it/portale/nuovocoronavirus/dettaglioFaqN uovoCoronavirus.jsp?lingua=italiano\&id=228\#11 (Erişim Tarihi: 10.03.2020).

İtalya ve Koronavirüs (2020). https://www.cnbc.com/2020/03/09/italyextends-its-quarantine-to-the-entire-country-pm-asks-residents-tostay-athome.html;https://www.gov.uk/foreign-travel-advice/italy, https://www.theguardian.com/world/2020/mar/04/italy-ordersclosure-of-schools-and-universities due-to-coronavirus, https://www.bbc.com/turkce/51814168 (Erişim Tarihi: 10.03.2020).

Mahase, E. (2020). Coronavirus: global stocks of protective gear Yeni Koronavirüs (COVID-19) Salgını ve Turizm Faaliyetlerine Etkisi aredepleted, with demand at "100 times" normal level, WHO warns. BMJ 2020;368:m543 doi: 10.1136/bmj.m543 (Published 10 February 2020). https://www.bmj.com/content/bmj/368/bmj.m543.full.pdf. (Erişim Tarihi: 06.03.2020).

Quilty B. J , Clifford S., CMMID nCoV working group , Flasche S., ve Eggo R.M . (2020). Effectiveness of airport screening at detecting travellers infected with novel coronavirus (2019-nCoV). EuroSurveill. 2020;25(5):pii=2000080. https://doi.org/10.2807/1560-7917.ES.2020.25.5.2000080.

Rodriguez-Morales, AJ., Gallego, V., Escalera-Antezana, JP., Mendez, CA., Zambrano, LI., Franco-Paredes, C., Suárez, JA., Rodriguez-Enciso, HD., Balbin-Ramon, GJ., Savio-Larriera, E., Risquez, A., ve Cimerman, S. (2020). COVID19 in Latin America: The implications of the first confirmed case in Brazil. Travel Med Infect Dis. 2020 Feb 29:101613. doi: 10.1016/j.tmaid.2020.101613.

T.C. Sağlık Bakanlığı, Türkiye Hudut ve Sahiller Sağlık Genel Müdürlüğü, Seyahat Sağlığı, (2020). Dışişleri Bakanlığının Yeni Koronavirüsten (COVID-19) Dolayı Seyahat Uyarıları. https://www.seyahatsagligi.gov.tr/Site/KoronaVirusSeyahatDuyurul ari, (Erişim Tarihi: 10.03.2020). 
T.C. Sağlık Bakanlığı, Halk Sağlığı genel Müdürlüğü, COVID-19 (2019-n CoV Hastalığı) Rehberi (Bilim Kurulu Çalışması) (2020). T.C. Sağlık Bakanlığı, 25 Şubat 2020. (Erişim Tarihi: 26.02.2020).

T.C. Sağlık Bakanlığı Türkiye Hudut ve Sahiller Sağlık Genel Müdürlüğü, Koronavirüsler $\quad$ Raporu, $\quad 10 \quad$ Ocak 2020. https://www.seyahatsagligi.gov.tr/Site/HaberDetayi/2208; https://www.seyahatsagligi.gov.tr/Site/koronavirus. (Erişim Tarihi: 28.02.2020).

Wilson, M.E. ve Chen, L. H. (2020). Travellers give wings to novel coronavirus (2019-nCoV). Journal of Travel Medicine, 2020, 1-3. https://doi.org/10.1093/jtm/taaa015. (Erişim Tarihi: 09.03.2020).

Yusuf ACAR, World Health Organisation, Coronavirus Disease (COVID-19) Outbrake 4 (1) 2020 (2020). https://www.who.int/emergencies/diseases/novelcoronavirus-2019, (Erişim Tarihi: 26.02.2020).

UNWTO Statement On The Novel Coronavirus Outbreak, https://webunwto.s3.eu-west-1.amazonaws.com/s3fs-public/2020 02/31012020\%20Coronavirus\%20EN.pdf 31 Jan 2020. Madrid, (Erişim Tarihi: 10.03.2020).

UNWTO Tourism and Coronavirus Disease (COVID-19). (2020). https://www.unwto.org/sustainable-development/resilience-oftourism, (Erişim Tarihi: 10.03.2020).

UNWTO Impact Assessment of the COVID-19 Outbreak on International Tourism. https://webunwto.s3.eu-west-1.amazonaws.com/s3fspublic/2020-03/UNWTO-Impact-Assessment-COVID19.pdf, (Erişim Tarihi: 10.03.2020).

WHO Global Research on Coronavirus Disease (2020). https://www.who.int/emergencies/diseases/novel-coronavirus2019/global-research-on-novel-coronavirus-2019-ncov, (Erişim Tarihi: 06.03.2020).

WHO Health Topics, Coronavirus (2020). https://www.who.int/healthtopics/coronavirus\#tab=tab_1, (Erişim Tarihi: 22.03.2020).

WHO Situation Reports (2020). https://www.who.int/emergencies/diseases/novel-coronavirus2019/situation-reports/, (Erişim Tarihi: 09.03.2020).

WHO Coronavirus disease 2019 (COVID-19) Situation Report - 48. (2020). https://www.who.int/docs/default-source/coronaviruse/situationreports/20200308-sitrep-48-covid-19.pdf?sfvrsn=16f7ccef_4. 
(Erişim Tarihi: 09.03.2020).

WHO Coronavirus disease 2019 (COVID-19) Situation Report -49 (2020). https://www.who.int/docs/default-source/coronaviruse/situationreports/20200309-sitrep-49-covid-19.pdf?sfvrsn=70dabe61_4, (Erişim Tarihi: 10.03.2020).

WHO Coronavirus disease 2019 (COVID-19) Situation Report -50 (2020). https://www.who.int/docs/default-source/coronaviruse/situationreports/20200310-sitrep-50-covid-19.pdf?sfvrsn=55e904fb_2, (Erişim Tarihi: 10.03.2020).

\section{ETIK Ve BILLIMSEL ILKELER SORUMLULUK BEYANI}

Bu çalışmanın tüm hazırlanma süreçlerinde etik kurallara ve bilimsel atıf gösterme ilkelerine riayet edildiğini yazar(lar) beyan eder. Aksi bir durumun tespiti halinde Güncel Turizm Araştırmaları Dergisi'nin hiçbir sorumluluğu olmayıp, tüm sorumluluk makale yazar(lar)ına aittir.
Yeni Koronavirüs (COVID-19) Salgını ve Turizm Faaliyetlerine Etkisi

- 21 